\title{
On an Armenian Word List from the Cairo Geniza
}

\section{Citation}

Russell, James R. 2013. On an Armenian word list from the Cairo Geniza. Iran and the Caucasus 17(2): 189-214.

\section{Published Version}

doi:10.1163/1573384X-20130205

\section{Permanent link}

http://nrs.harvard.edu/urn-3:HUL.InstRepos:10880590

\section{Terms of Use}

This article was downloaded from Harvard University's DASH repository, and is made available under the terms and conditions applicable to Open Access Policy Articles, as set forth at http:// nrs.harvard.edu/urn-3:HUL.InstRepos:dash.current.terms-of-use\#OAP

\section{Share Your Story}

The Harvard community has made this article openly available.

Please share how this access benefits you. Submit a story.

Accessibility 
ON AN ARMENIAN WORD LIST FROM THE CAIRO GENIZA.

By James R. Russell, Harvard University.

(Symposium on the anniversary of the journal Iran and the Caucasus, Erevan, Armenia, July 2011)

“... No one in the world except Armenians. No European can ever really understand or speak your language."

(Gabriel Bagratian's French wife Juliette, in Franz Werfel, The Forty Days of Musa Dagh, translated from the German by Geoffrey Dunlop, New York: Viking Press, 1934, p. 178)

T'eguz alim, t'eguz č'slim, mejlisnerun saz č'i paksi, T'e ku paksim, k'iz ku paksim, ašxaris me maz č'i paksi, Sayat' Novu gerezmanən Hind, Habaš, Arab mi ani.

"To be or not to be, no party will lack for a lute because of me;

This world lacks not for a hair; if I lack, I lack for thee-

Let not a Hindu, Ethiop, or Arab Sayat' Nova's gravedigger be."

(Morus Hasrat'yan, ed., Sayat' Nova, Erevan: Haypethrat, 1963, p. 20, no. 10: final stanza of Dun èn glxen, AD 1753)

This study deals with a short text on a small piece of paper found in the Cairo Geniza. It is likely to be nearly a millennium old, and consists of a list of twenty JudaeoArabic words and phrases with their equivalents in Armenian written in Hebrew script. Very few such documents are known and there are good reasons that they are highly unusual. For although small numbers of Jews have lived in Armenia over the centuries, the country has no indigenous Jewish community in the sense that all the nations surrounding it do. ${ }^{1}$ There are Judaeo-Georgian, Judaeo-Persian, Judaeo-Kurdish,

\footnotetext{
${ }^{1}$ In the Soviet period, between one and two thousand Russian-speaking Jews settled in Armenia - the most ethnically homogeneous of all the Soviet Republics - mostly in Erevan. Dimitri Slivnyak became an Armenologist and worked in the Matenadaran, where I first met him; later he migrated to Israel and Hebraized his name to Mordechai Even-Vered. Some local Armenians married Jews: my friend Ruben Malayan, who has lived in both Armenia and Israel, is the offspring of such a union. In Israel itself there are Arabic-speaking Armenian communities in Galilee; Hebrew-speaking Armenians in Haifa; Russianand Armenian-speaking Soviet immigrants from Armenia in the Tel Aviv area; and in the Armenian Quarter of the Old City of Jerusalem and environs, both the centuries-old $k^{\prime}$ 'ałak 'ac ' $i$ "city" people with their dialect and the descendants of Genocide-era refugees speaking Western Armenian dialects. The State of Israel, like the United States, has for the sake of relations with Turkey refused officially to recognize the
} 
Mountain Jewish Turkic and other ethnolects, but there is no dialect that can properly be called Judaeo-Armenian. Tigran II ("the Great") brought Jewish settlers to Armenian towns in the first century $\mathrm{BC}$, and $\mathrm{P}^{\prime}$ awstos Buzand records the presence of large numbers of Jews in Armenia in Sasanian times. Iranian invading armies, notably in the reign of Shapur II in the fourth century $\mathrm{AD}$, drove most of these communities, it seems, into exile. In Diaspora settings such as Constantinople where the two communities have lived in close proximity to each other, Armeno-Jewish relations have been sometimes cordial, but at other times those of minorities in tense competition. Traditional Christian anti-Semitism sometimes mars Armenian attitudes towards Jews and is evident in such works as Eremia Çelebi Kömurciyan's The Jewish Wife. The contempt seems to have been mutual: one popular Jewish belief has branded Armenians, astonishingly, as the descendants of the Amalekites of the Bible, the very embodiment of human evil whom God Himself cursed. In Yiddish, for instance, the Hebrew word timkhe, half of the emphatically repetitive phrase yemakh timkhe - God's command that the Amalekites be utterly blotted out - was a code name for Armenians. So a list of Armenian words and phrases in Hebrew script is of great intrinsic linguistic interest; but it richly deserves to be mined also for its social and cultural content and context, and its rarity warrants even imaginative speculation about its purpose. The rarity of documents may suggest that Armeno-Jewish interaction was correspondingly sparse, but these two dynamic, versatile peoples of the Near and Middle East often paralleled and overlapped each other in location and social station, in craft and profession, in travel and trade; so the written evidence may hint, in fact, of a much richer reality.

With the important exception of "Assyrian" Christians, some of whom are still bilingual in Neo-Aramaic and Armenian, and to a lesser extent, some Kurds (both Muslim and Yazidi) and Greeks living in the Armenian highlands, few foreigners except for scholars and a poet or two, and it would seem, still fewer Jews of the Near East, have needed, wanted, or troubled in most recent times to learn Armenian. ${ }^{2}$ But that was not always the case; and one indication is another manuscript whose data will be cited presently to corroborate the Geniza fragment. This is a dictionary in Arabic script of six different languages - a hexaglot - compiled in the fourteenth century for a king at Aden, in southern Yemen. The languages are Arabic, Persian, Turkish, Greek, Armenian, and

Armenian Genocide, though the Hebrew University of Jerusalem holds an official commemoration of 24 April every year (this writer was its keynote speaker in 2009). Armenia in turn, also for justifiable, even vital political and economic reasons, maintains good relations with the Islamic Republic of Iran, whose present régime officially denies the Holocaust, advocates the destruction of Israel, is implicated in acts of terrorism against Israeli and Diaspora Jews, and disseminates at state expense such anti-Semitic propaganda as the notorious forgery, Protocols of the Elders of Zion. Many Armenians in the Near East are politically anti-Israel and pro-Arab. Social contacts and even marriages between Armenians and Jews are frequent and happy, but communal and official relations are often not very close. However there are no natural reasons for enmity between the national entities of the Jews, Armenians, and Iranians. One hopes for a much brighter future.

${ }^{2}$ Lord Byron famously learnt Armenian at the Mekhitharist monastery of S. Lazzaro in Venice and opined that it was a difficult language, but one that repaid the effort of learning it. Some of the Russian poets who collaborated with Valery Bryusov on the 1916 Anthology took a superficial interest in the language; and it intrigued Osip Mandelstam, who tried to learn a bit more, and as the Acmeist author of the cycle Kamen', "Stone", liked the phonetic collocation, evocative of the hardness and inner air of the skull, of Armenian glukh, "head", and Russian glukhoi, "hollow". 
Mongol; and it is reasonably inferred that these six were considered particularly important and useful in the 1300's, the zenith of the Mongol empire. At that time the political center of Armenia was the Cilician kingdom, on the northeastern coast of the Mediterranean, whose form of the spoken Armenian language is, indeed, the closest to both the Geniza fragment and the hexaglot. One recalls that a Cilician prince, Het' um, had completed in 1307 his narrative, in Old French, of a trip some decades earlier to the Mongol capital, Karakoram - the Middle English translation, A Lytell Chronicle, with its author's name quaintly rendered as Haithon, was rather a bestseller in the British Isles. The Armenians of the centuries embraced by these two glossaries were a nation of political and economic importance who inhabited a homeland that encompassed large parts of modern Georgia, Azerbaijan, and Iran on the north and east, parts of northern Iraq and Syria on the south, and much of the Anatolian peninsula. Armenians were a major presence in Constantinople, from the imperial court on down, in Jerusalem and most other cities, holy places, and monastic centers of the land of Israel, and, as we shall see presently, in Egypt. The only surviving remnant of that homeland is the Transcaucasian survivor state in the northeast; and the Armenian people are scattered to remote diasporas, playing a modest role in world affairs. But in the period under discussion, Armenia was neither small nor peripheral to the Near and Middle East but central to it in demography, politics, and economy; its language, of corresponding importance. To see Armenia as small is to peer through the wrong end of the telescope; but historical myopia can warp one's perceptions, and such distortions can affect more than scholarship.

For instance, it is known from the Vita of Maštoc' by Koriwn that the Armenian saint created first the Armenian alphabet, then at the invitation of Georgians and Albanians and in collaboration with them invented also the alphabets of the two other Christian peoples. But lately the invention of the scripts is attributed to a "pan-Caucasian effort", a term as vague as it is imprecise - ancient Armenia was very much more and other than a "Caucasian" land. Most of the loan-words in Georgian from Middle Iranian - terms that are of considerable religious, administrative, military, and culture significance - were not borrowed directly from the Parthians or Persians, but through the intermediary of Armenian. Yet Georgian scholars who certainly ought to know better tend to cite the Armenian forms as parallels, rather than sources. If a British scholar were to insist that the numerous Romance vocabulary in English derived, not from Old French, but directly from Roman Imperial Latin we should view the distortion as an extension of the old animus against that pleasant land across the Channel of snails, garlic, red wine, and, well the conquering Normans, into scholarship. The absurdity is less amusing when one considers that the Georgian diminution of Armenia proceeds together with the deArmenization of Tiflis, cultural and physical ethnic cleansing rubbing each other's hands, as it were. There are further overtones: at the conference of the Association Internationale des Etudes Arméniennes, the great Georgian scholar Zaza Aleksidze devoted his plenary lecture to a call to Armenians for pan-Caucasian unity. Though the lecture had an eirenic purpose and stressed the many things the two peoples have in common, its designation of Armenia as Caucasian distorts and diminishes the country, while the political result of such a summons would be to set Armenia alongside Georgia in the latter's dispute with the Russian Federation - to Georgia's benefit, perhaps, but to Armenia's peril. It is not 
one's purpose here to inaugurate a polemic or to advance a counter-agenda, only to insist firmly upon the integrity and accuracy of scholarly method in the basic premises of historical geography and linguistics. So I invite you a thousand years into the past, to listen to a kind of Armenian very like the standard Western Armenian today, but in a Middle East where Armenia was a major presence, a world that was in many other ways, too, radically different from our own.

But first, what is the Cairo Geniza? Jewish law prohibits the disposal of any writing with the Hebrew name of God, such as a Torah scroll or prayer book too worn or damaged for licit liturgical use. It must be ceremonially buried or confined to a receptacle for storage; and tradition gradually extended the prohibition to any document in the Hebrew script, which was sacred because it was employed to write the Bible. Depositing papers in a storeroom at the back of a synagogue was cheaper than carting them off to the graveyard, though burial was done sometimes, too. Such a place of storage is called a geniza, from the Hebrew root $g-n-z$, "to conceal", itself a loan from the Iranian word for a treasure (cf. Persian ganj, the Armenian loan-word ganj, the toponym Ganjak or Ganja, Hebrew gizbar from * ganzabara-, "treasurer", etc.). The most famous geniza is that of the Ibn Ezra synagogue of Fustat, old Cairo, which was discovered by scholars in the late nineteenth century. Its many thousands of fragments, most of which belong to the Fatimid and early Ayyubid periods - roughly the first quarter of the second Christian millennium, though there are also documents of much later date - deal with every aspect of the economic, legal, religious, cultural, and material life of Jewish communities in Egypt, North Africa, the Land of Israel, and Spain in particular but with many other regions and peoples as well. It is thus a treasure house indeed, and Geniza studies have transformed our understanding of Jewish life and letters in the Middle Ages. The principal languages of these documents are Hebrew and Aramaic and the Judaeo-Arabic ethnolect, with much material also in other languages including Judaeo-Persian, JudaeoSpanish (Ladino), Judaeo-Greek, and even Judaeo-German (Yiddish). Most of the Geniza documents were removed to Cambridge University, though smaller collections exist in many other places, not all of them edited; and Solomon Schechter, S.D. Goitein, Shaul Shaked, and other titans of scholarship have pored over and published them for over a century. Very many still remain to be studied; and the fragment to be discussed here, which was read and published only recently, affords an idea of the treasures the Geniza has yielded and of the new discoveries its riches may yet make possible. ${ }^{3}$

In 2005 the Geniza scholar and eminent professor of Arabic, Dr. Avihai Shivtiel, in collaboration with Prof. James Clackson of Cambridge University, a Classicist and Armenologist perhaps best known for his lucid work on the important but vexed question of the kinship of early Armenian to Greek, published a brief article on the fragment T-S NS 38.79. ${ }^{4}$ This is a document from the Geniza of twenty words and phrases in Judaeo-

\footnotetext{
${ }^{3}$ For a good survey of the history of the discovery of the collection and its contents and researchers, see Adina Hoffman and Peter Cole, Sacred Trash: The Lost and Found World of the Cairo Geniza, Nextbook series, New York: Schocken, 2011. The Cairo Geniza has inspired also Amitav Ghosh's book In an Antique Land: History in the Guise of a Traveler's Tale (New York: Knopf, 1992). Perhaps this paper is in its way cultural history in the guise of a study of language.

${ }^{4}$ Avihai Shivtiel, "A Judaeo-Armenian and Judaeo-Arabic Word-list from the Cairo Genizah," in Philip S. Alexander et al., eds., Studia Semitica: The Journal of Semitic Studies Jubilee Volume, Journal of Semitic
} 
Arabic with their equivalents in Armenian transliterated into the same semi-cursive, square-character Hebrew letters employed for the Arabic. The fragment, which measures $17 \times 6.5 \mathrm{~cm}$, is dated on the basis of the type of paper and the palaeography to the tenthtwelfth centuries AD. The language is not identified in the text itself as Armenian; and Shivtiel speculates that the fragment may have been part of a larger phrase book. The latter would, I think, have been polyglottic, rather than a continuation of the Armenian list; for the range and arrangement of the latter suggests it is self-contained and is not likely to have been a part of a longer glossary with more and other Armenian words on diverse topics. The list of the Judaeo-Arabic words and phrases to be translated is as follows: "bread" (al-khubz), "meat" (al-lahm), "water" (al-mā), "wine" (al-nabid $)$, "rose" (al-ward), "apple" (al-tuffāh), "pear" (al-kummathrā), "woman" (al-mar'ah), "virgin" (al-bint al-bikr), " your mother" (ummak), "your father" (abük), "beautiful [lit., "salty"] face" (al-wajh al-malīh), "female singer" (al-mughanniyah), "white" (al-abyad), "black" (al-aswad), "tax collector" (jilwa'az), "come!” (ta'āl), "go!” (imdi), "sit!” (ijlis), and "how are you" (kif ant). The corresponding Armenian forms are: hads (for hac ), mis, shur (for either jur or "Western Armenian"/čur/), kini, vart (for vard or /vart/), khnzor (for xnjor), danz (for danj), khugnigh (probably $k$ ' $u$ "thy", with diminutive knik or /gnig/ "wife, little woman"), kays (for koys), mayr (without possessive suffix), dad (instead of hayr, and without possessive suffix), aghya akhshkin (ateay, "salty", with gen. of ałjik, "girl"), kusan (for gusan or /kusan/, "minstrel, bard" without gender suffix), aspidag (for

Studies Supplement 16, Oxford: Oxford University Press, 2005, pp. 139-143; and see also James Clackson, "An Armenian/Judaeo-Arabic Word-List in Cambridge," in Barlow Der Mugrdechian, ed., Between Paris and Fresno: Armenian Studies in Honor of Dickran Kouymjian, Costa Mesa, CA: Mazda, 2008, pp. 241246. I am indebted for this reference to my dear friend and valued colleague Professor Firuza Abdullaeva and to Prof. Geoffrey Khan, both of Cambridge University; and for his provision of references on Armenians in Egypt, to Marc Mamigonian, director of the National Association for Armenian Studies and Research, Belmont, MA. I have the pleasure also to acknowledge a most friendly and informative reply to my query by Dr. Ben Outhwaite of the Taylor-Schechter Geniza Research Unit of the Cambridge University Library; and I thank the Syndics of the Library for kind permission to publish the fragment, whose classification number is T-S NS 176.2. The existence of the Geniza fragment was helpfully brought to my attention, though in general terms and without specific reference or description, by a most learned anonymous reader of my article, "On An Armenian Magical Manuscript (Jewish Theological Seminary, New York, MS 10558)," (in publication, 2011, Proceedings of the Israel Academy of Sciences and Humanities): I record here my thanks for his valuable observation. The JTS manuscript, which can be dated to $c a$. AD 1892, has annotations in Hebrew and Judaeo-Spanish (Ladino), as well as a list of the Armenian names of the signs of the Zodiac transliterated in Western Armenian pronunciation into square-character Hebrew. Both the Geniza and JTS MSS are examples of transliteration of a foreign language. As we have seen, there is no evidence, however, of a particular form of Armenian spoken by Jews analogous to such hyphenatable ethnolects as Yiddish, Ladino, Judaeo-Persian, etc. Some Jewish graves have been found in Armenia from roughly the same period as the Geniza text, and Professor Michael Stone has studied and published them. But these are inscribed in Hebrew/Aramaic only, and there is no context for the community to which they belonged. On the existing, meager evidence one is inclined to think they were relatively transient Iranian Jews who employed Armenian stonemasons. There is no historical evidence of a long-term, indigenous Jewish community in Armenia after the Sasanian period; and there is no Jewish literature in Armenian, which is exclusively and entirely Christian. From what we can glean from studies by Avraham Galante and others, Jews who lived in Armenian areas of Ottoman Anatolia spoke Arabic, Neo-Aramaic, Kurdish, and Turkish, but never Armenian. The designation "Judaeo-Armenian" is at best imprecise and at worst misleading, and should, consequently, be set aside. This is not meant in any way to detract from the immense value of Shivtiel's contribution or of Clackson's remarks, which are all the more remarkable and praiseworthy for the remoteness of this material from the latter's branch of Armenology. 
spitak or /spidag/, with on-glide: /aspidag/), siyav (Classical Armenian seaw), *atstpan mart (a difficult word to decipher, perhaps Middle Armenian acpan mard, "goat-herd man", cf. Arm. aycapan "goat-herd"), ariyag (cf. Middle Armenian arek), aknah (gnay or /knay/, either prefaced by an exclamatory $A h$ ! or else with on-glide: /əknál), nist (Classical Armenian nist), and in shkurnas (thus, as two words with Hebrew final nun delineating the first, perhaps to indicate stress on the first syllable; so possibly from a form inč " ku arnes, "What are you doing?" like modern American "How ya doin'?").

A number of these forms are paralleled by the Rasūlid hexaglot, the $14^{\text {th }}$-century dictionary in Arabic from Yemen, to which one referred above. We find there $h$ 's /hats/ for "bread", mys /mīs/ for "meat", t'nz /tandz/ for "pear", v'rt /vārt/ for "rose", khnzwr $/ k h n d z \bar{o} r /$ for "apple", 'ghyk/aghēk/ for "good", and syw/sēv/ for "black". "Sit!" is nyst Inist/ as in the Geniza fragment, but "Go!" is simply $k n$ " $/ k n \bar{a} /$ without prothetic $a$. "Come!" is 'ryk/arēk/ rather than ariyag, a development to be expected after two centuries. The word for woman in the hexaglot, $k n y k / k n \bar{k} k$, has the same diminutive ending as in the Geniza, rather than kin. (For al-tâhir, "pure", the Armenian of the hexaglot again employs a diminutive, srbkyk/sarbkik/.) The hexaglot has an exhaustive hippological section, so it distinguishes finely between Armenian jrm 'k /jermāk/ "white" in the sense of a white horse, the kind that horse people nowadays call a "gray" (Arabic $a l$-ašhab), and the generic word for "white" (Arabic al-abyad), sbyd'k/asbìdāk/. Among the deficiencies of the Arabic script are the use of $k$ for both $k$ and $g$ and the use of matres lectionis - place-holding vowel-letters like alif and $y a$ - to represent either a long $a$ or $i$ or simply a place where another language has that vowel, either short or long (and in the case of $y a, i$ or $e$, too). Arabic has no $t s$ or $d z$, so we can only suppose $h$ 's is /hats \% It has no $p$, so it is only on the strength of the $d$ in place of $t$ in the word for white, 'sbydk, that we can infer the scribe meant to render asbidak (or, indeed, asbidag?)—Classical and Modern Eastern Armenian spitak. The late great Hungarian Armenologist, Prof. Edmund Schütz, opted rightly, I think, to render Cilician forms where the Arabic posed such ambiguities. The Geniza fragment with its more precise Hebrew, published several years after the hexaglot, vindicates his judgment. ${ }^{5}$

I have transliterated or explained a number of the Armenian words differently at points from Clackson, who in his notes also distinguishes this or that form, on the basis of the voicing or lack thereof of the unvoiced stops of Classical Armenian, as "Western" or "Eastern". These voiced forms are indeed important and worthy of attention, since they attest vividly to dialect variation in Armenian, a feature of the language that undoubtedly existed from very early times. The political division of Persian and Roman spheres of influence in Armenia could have set in motion the processes that resulted in the sharper, later distinctions between the dialects of the Ottoman-ruled and Russo-Persian parts of the country. It is by now generally accepted that the division of a preponderance of the dialects of the language into reasonably delineable Western and Eastern categories as we now know them can be dated to about the $17^{\text {th }}$ century. Rather we deal, as the imperative

\footnotetext{
${ }^{5}$ See Peter B. Golden, ed., The King's Dictionary: The Rasūlid Hexaglot: Fourteenth Century Vocabularies in Arabic, Persian, Turkic, Greek, Armenian, and Mongol, Leiden: Brill, 2000. I am most grateful to Prof. Sebouh Aslanian of the University of California, Los Angeles, who called my attention to this valuable resource.
} 
for "Come!" suggests, with an early attestation of Middle Armenian, the language typified by the documentation of the Cilician kingdom, displaying the characteristically fluid phonology of that stage of the language. Moreover, the Hebrew transliteration of the form as ariyag suggests a transitional stage between an original ari ek and the later arek attested in Armenian manuscripts. ${ }^{6}$ Similarly transitional is the use of ateay, "made of salt", 7 for "pretty", before or alongside the addition of the diminutive that produced Middle and Modern Armenian atek. There are distinctly "Classical" forms, such as siyav (rather than modern sev) for "black" and nist (instead of nste or nstir) for "Sit!" The word for "white", /aspidag/, voices the unvoiced stops as the later Western dialects do; but the Middle Iranian loan-word spitak itself would now be characteristic of Eastern Armenian, the common term in Western being instead/Jermag/. The latter is a specialized and therefore secondary form, a particular shade of white, that has become general. It displays the demotion to common usage of a previously noble, hippological term, cf. Persian čarmeh, "a gray" (i.e., a white horse), as we have seen in the Rasūlid hexaglot, above. (For another example of the process, compare the change in Persian of the word dehqān from "landed nobleman" to "peasant". The wear and tear of usage tends to drag words down.) So an "Eastern" word, spitak, for white with "Western" pronunciation spidag is neither "Eastern" nor "Western" but truly Middle Armenian in every way. The possessive second person singular $k^{\prime} u$ is typical of Western dialects today, cf. Classical and Eastern $k^{\prime} o$. The pronunciation of koys, "virgin", as kays (the diphthong rendered by a Hebrew double yod) reflects a dialect variation, unless the double yy is a lapsus calami for the slightly rarer (in Hebrew) waw-yod, the downstroke of the waw in the Hebrew script of this period being only slightly longer than that of the yod (whose downstroke then was longer than it is now). But in support of dialect variation one may cite the name, Nairuz (for an original Nowrūz, lit. "New Light"), of an Armenian convert to Islam who fought to reconquer Antioch from the Crusaders in 1098, squarely in the middle, that is, of the period to which the word list is dated. ${ }^{8}$ The ancient Zoroastrian new year feast of Nowrūz, as we will see presently, was extremely popular in medieval Cairo and its observances may be of relevance to an understanding of the Armenian word list under discussion, as well. Another possible dialect form is hads for hac", "bread", suggesting the anomalous voicing of the aspirate $t s$ ' - unless the Hebrew writer meant simply for the sake of clarity to avoid use of the letter tsaddi, which was often used in the JudaeoArabic of the time not only to represent the sound $t s$, which exists in Hebrew and Aramaic but not Arabic proper, but also for the Arabic sounds sad or $d a d .^{9}$

Writing Armenian in foreign alphabets is not unprecedented. According to the hagiography of Koriwn, St. Mesrop Maštoc' himself, when inventing the Armenian script early in the fifth century, experimented with the enigmatic "Danielian" letters - perhaps a variant of Syriac adapted to Armenian, or the remnants of the old Aramaic

\footnotetext{
${ }^{6} \dot{\text { R.S. }}$ Lazaryan and H.M. Avetisyan, Mǐ̌in hayereni bararan ("Dictionary of Middle Armenian"), Vol. I, Erevan: Erevani Petakan Hamalsaran, 1987, p. 89.

${ }^{7}$ Miǰin hayereni bararan, Vol. I, p. 27.

${ }^{8}$ Seta B. Dadoyan, The Fatimid Armenians: Cultural and Political Interaction in the Near East, Leiden: Brill, 1997, p. 133. The Arabic term for "virgin" in the hexaglot lacks an Armenian equivalent.

${ }^{9}$ Peter T. Daniels and William Bright, The World's Writing Systems, New York: Oxford University Press, 1996, p. 729.
} 
heterographic system that was to endure in Zoroastrian Book Pahlavi. There are short transliterations of names and phrases into Greek, in both manuscripts and epigraphy (as well as a papyrus in Greek, written in Armenian letters): an undated bas-relief on the outer wall of Echmiadzin cathedral begs God's mercy on Daniēl, Tirēr (i.e., Tirayr), and Garikinios (i.e., Garegin). All these forms correspond to the phonology of Classical Armenian. In the eleventh century, a bronze caster left his name in Greek and Estrangela Syriac letters on the doors he had made, which now greet the visitor to the church of San Paolo fuori le Mura, at Rome: Staurakios, lit. "little Cross", and $k-t-s ̌-g$, i.e., Armenian Xač' $i k$, which means the same thing. The final unvoiced stop in the diminutive suffix, $-i k$, is voiced as a $g$, just as in later Western dialects and just as in several cases on our list from the Geniza! ${ }^{10}$

Who spoke the Armenian of the word list? Armenians had traveled to Egypt for many centuries, though from the evidence they were royal captives or tourists. Poor king Artawazd II was captured by Marc Antony in 34 BC, paraded in a triumph through Alexandria, and murdered three years later. ${ }^{11}$ Around AD 202, the Armenian king Xosrov I accompanied the emperor Septimius Severus (r. 193-211) to Egypt, and left a Greek inscription at Thebes: Khosroēs armenios idōn ethaumasa, "Xosrov the Armenian, seeing (this), I was amazed."12 Prof. Clackson has studied the Greek-in-Armenian papyrus mentioned above: found in the $19^{\text {th }}$ century and probably in the Fayyūm, it now reposes in the Bibliothèque nationale de France. Clackson places it in the context of Greek educational papyri found in Egypt: it contains some seventeen lines of short conversational phrases, conjugations of verbs, word-lists by subject, and some short stories and maxims. Scholarly speculation about the author is divided: he could have been a merchant, maybe a soldier. ${ }^{13}$ But it seems that Armenians in Egypt before the Muslim conquest in $\mathrm{AD} 640$, such as the man who wrote the papyrus, were numerous enough, and resident long enough, to take a serious interest in the Greek culture of the Byzantine rulers.

In the first centuries of the second millennium there were Armenians in Egypt from the heartland of the country around Van, many others still would have come from Syria, and Armenian converts to Islam were prominent in the Fatimid hierarchy, though the latter were by reason of their station less likely to mix socially with middle-class Jews, nor, indeed, to need words of greeting and the like translated from Arabic for them.

${ }^{10}$ J.R. Russell, "On Armeno-Iranian Interaction in the Medieval Period," in Au Carrefour des religions: Mélanges offerts à Philippe Gignoux, Res Orientales, Vol. VII, 1994, p. 235 n. 1 with refs. (repr. in J.R. Russell, Armenian and Iranian Studies [=AIS], Harvard Armenian Texts and Studies 9, Cambridge, MA, 2004, p. 593). On texts in other languages written in Armenian letters, see Hakob P'ap'azyan, "Mesropatar aylalezu grakanut "yan masin" ("On literature in other languages employing the letters of Mesrop"), Banber Matenadarani 7, Erevan, 1964. In recent centuries, it has been very common for Armenians in Georgia to

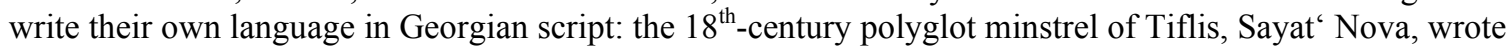
Armenian in Georgian mkhedruli letters while using Armenian script to write Tatar (Azeri Turkic).

${ }^{11}$ J.R. Russell, Zoroastrianism in Armenia (= Zor. Arm.), Harvard Iranian Series 5, Cambridge, MA, 1987, p. 94.

${ }^{12}$ Russell, Zor. Arm., p. 119.

${ }^{13}$ Dickran Kouymjian, "History of Armenian Paleography," in Michael Stone et al., Album of Armenian Paleography, Aarhus: Aarhus University Press, 2002, pp. 59-63, especially p. 60 n. 226 with references to Clackson's several articles on the papyrus; and p. 63 illustration 16, the papyrus. 
The Armenian written by the eleventh-century bronze caster Khach'ig is phonetically like the kind we encounter in the word list; and since he used Estrangela Syriac script it is reasonable to suppose he was born and learnt his craft in a city with a substantial Armenian population where Syriac was dominant at the time. The obvious candidate is of course Edessa, modern Urfa, whose fall to the Muslims about a century later St. Nersēs Šnorhali (d. 1173) was to chronicle in the long poetic lament, Otb Edesioy: St. Nersēs, who lived not very far away at Hromkla near Aintab (modern Turkish Gaziantep), relied on eyewitness accounts. He is known to have written in the ašxarhakan, "secular" Armenian speech - that is, the Middle Armenian equivalent of the vernacular we now call, with reference to Modern Armenian, ašxarhabar, "vernacular" - in distinction to grabar "book language", i.e., the Classical Armenian that was then still very much alive as a literary medium. This would have been the language Khach'ig spoke; and if the Catholicos wrote it, then it was the common speech of the noble and the wealthy as well. One might hazard the guess, therefore, that the Armenian informant whose pronunciation of his native tongue our writer of Judaeo-Arabic transliterated on an ad hoc basis, had arrived at Cairo from Syria: from Edessa, or perhaps Antioch. Whatever his own origin, the number of his compatriots in the Fatimid metropolis was, as we have seen, heterogeneous. It had recently become much larger, though it was already of long standing. Two Armenian Cross-stones ( $x a c^{\prime} ~ k ' a r$ ) found in Cairo are dated to the tenth century; and the huge fresco at Deir al-Abyad, the "White Monastery" near Sohag, dated 1124-1125, has Armenian inscriptions and was the work of an Armenian artist. By the late eleventh century, a number of Armenian converts to Islam were prominent in the Fatimid state. In the period of mass migration and chaos following the battle of Manazkert (Manzikert, to Byzantinists) in 1071, some thirty thousand Armenians fled the Byzantines and Seljuks to settle in Egypt. Armenian architects and builders constructed the walls and gates of the capital under the supervision of Badr al-Jamāli (1075-1094), an Armenian who served as vizier of the Caliph al-Mustansir (1036-1094). In the late 1070's the Armenian Catholicos Gregory II Martyrophilus (Vkayaserr), son of the scholar and Armeno-Byzantine administrator Grigor Magistros Pahlawuni (d. 1058), made his famous journey to Egypt and, with the approval of the Muslim authorities, appointed his nephew Grigoris primate of the newly established diocese of the country. ${ }^{14}$ By the twelfth century, when a Muslim Armenian named Bahrām served as vizier, some thirty Armenian churches and monasteries are known to have existed at Cairo and in other major cities of Egypt. ${ }^{15}$ Thus there were both prominent Muslim converts and numerous Christian Armenians in Egypt at the time the word list was compiled.

What did Armenians of the period in Egypt do? The Geniza documents themselves mention Armenian craftsmen and merchants in Cairo who traded in carpets, curtains, silk, and mother of pearl; one Nahray b. Nissīm mentions "half an Arjishī robe",

\footnotetext{
${ }^{14}$ Angèle Kapoïan-Kouymjian, L'Égypte vue par des arméniens, Paris: Singer-Polignac, 1988, pp. 2-15; plates 1-IVa for the fresco. The visit of the Catholicos was important enough to merit mention by the major Armenian chroniclers over the next two centuries, including Matthew of Edessa, St. Nersēs Šnorhali, Kirakos of Ganjak, and Smbat.

${ }^{15}$ Dadoyan, pp. 9, 82, 87, 94, and 105.
} 
i.e., from Arčěš, an Armenian city on the north shore of lake Van. ${ }^{16}$ A letter requests various carpets including a "red Armenian rug (bisāt)." ${ }^{17}$ Close attention to the many shades of color is a salient feature of Geniza texts dealing with realia, and of all hues it is the distinctive Armenian red that others have noted and prized through history. In the United States and other modern Western countries, the Armenian or Persian rug merchant is something of a stereotype; and the Oriental carpet is a superfluous, luxury item. One must resist such myopia in attempting to understand Fatimid Egypt: there, as S.D. Goitein demonstrated, such items of furniture as tables, chairs, and beds, so common in GrecoRoman antiquity and in the West today, were few. Domestic arrangements bore the mark of an Arab desert culture, not an ancient urban one. Rugs, mats, curtains, and hangings of all kinds played a correspondingly greater role in household furnishings than they do now. And the Muslim and Jewish faiths, while enjoining abstemiousness at table, urged their adherents to be lavish in their clothing, which was as rich in color and material as its wearer could afford: the tailor's profession was not a lowly one. Shelomo Goitein, after an exhaustive study of fabrics, colors, and garments mentioned in the Geniza documents, exclaimed that "medieval males... must have looked like tropical singing birds"! The role of the Armenians in the rug and textile trade was vital and central to the economy. It is to be imagined that the Armenian whom the Jewish owner of the word list was seeking to impress with a few words of the former's own tongue was a fellow tradesman, possibly a merchant of means and importance whose friendship was worth the effort, one whom he might encounter at a social gathering.

It is apparent from the contents of the word list that it was intended for social purposes, rather than, say, a legal case, a purely business transaction, or a religious disputation. What would such a social event involve? Let us attempt a sort of rough deduction. While working on this paper I wrote to a wide range of friends and colleagues, without telling them the contents of the word list from the Cairo Geniza but explaining my work on it, and asked that they compile for me a list of the twenty most important words and phrases they would want to know in a foreign language for a social encounter. Only a few were so courteous as to respond; but they and their replies are sufficiently diverse for the data they provide to be of some interest. Michele Moramarco, in his fifties, a friend in Reggio Emilia, Italy, writes: 1. Who are you? 2. Where do you come from? 3. I am... 4. I come from... 5. Do you like? 6. I like... 7. Health 8. Food 9. Water 10. Music 11. Family 12. Friendship 13. Love 14. Goal 15. Time 16. God 17. Ideas 18. Job 19. Hobby 20. Future. Dr. Sergio La Porta, forty, a native of New York City and Professor of Armenian Studies at Fresno State University, California, offered the following list, with a witty $21^{\text {st }}$ item: 1 . Hello 2 . Goodbye 3 . How are you? 4 . How much does it cost? 5. Nice to meet you. 6. My name is... 7. Bread 8. Water 9. Market 10. Where is 11. River 12. Center 13. Gate 14. Church 15. Street 16. Sun 17. Moon 18. Up 19. Down 20. Excuse me. 21. Toilet. Dr. Peter Manuelian, also in his forties, a native of

\footnotetext{
${ }^{16}$ Arčěš, an ancient Urartean foundation, was partly submerged in the Middle Ages and acquired the same sort of legends that accreted around other sunken cities, such as Atlantis, Russian Kitezh, and East Anglian Dunwich: see J.R. Russell, “The Shrine Beneath the Waves,” RES 51, Cambridge, MA, Spring 2007, pp. 136-156; Russian tr. in Rossiya XXI, Moscow, 2007, pp. 10-43.) On the robe, see S.D. Goitein, $A$ Mediterranean Society, Vol. 4, Berkeley and Los Angeles: University of California Press, 1983, p. 182.

${ }^{17}$ Goitein, Vol. 4, pp. 119, 123, 126, and 197.
} 
Boston and Professor of Egyptology at Harvard, suggests: 1. Greetings 2. How are you? 3. Yes/no 4. Where is...? 5. Do you have...? 6. I want... 7. Water 8. Food 9. Please give me... 10. My name is... 11. Your name is... 12. He 13. She 14. We 15. They 16. Sleep 17. House 18. Mother/father 19. Sister/brother 20. Son/daughter. Kristina Arakilyan, a native of Uzbekistan now resident in Brooklyn, New York, and an undergraduate at Harvard, has this list: 1. Hello. 2. My name is X. 3. I am from X. 4. It is nice to meet you. 5. Yes 6. No 7. Morning 8. Afternoon 9. Evening 10. Night 11. Please help me. 12. Thank you. 13. Where is X? 14. Inn 15. Transportation 16. Water 17. I don't understand. 18. How much is it? 19. I'm sorry. 20. Goodbye.

Where is it? How much does it cost? Help! Excuse me, I'm sorry, goodbye! The younger the source, the more the list seems to be influenced by phrase books for travelers: more Kafka looking anxiously for the railway station early in the morning in an unfamiliar city than a traveler breaking bread with a stranger. All include some form of introductory greeting; two mention food in general, one specifies bread, and all the lists have water. One mentions family; another, more specific family relationships. None mentions any colors, fruits, or flowers. And only one of my four interlocutors, perhaps not surprisingly the eldest (remembering better days than this unarmorial age) and the one living closest to the Mediterranean, includes the items "love" and "music" on his list: we recall the little woman, pretty face, and (female) singer of the Geniza manuscript. Khach'ig and Avraham meet, and the latter trots out the basic pleasantries: Ariyag, nist, inškurnas? Would you care for hads, mis, a cup of šur? What are the names of your dad and mayr? How is $k^{\prime} u$ knig? That's a nice sspidag coat and siyav hat. ${ }^{18}$

But the occasion and the vocabulary appropriate to it are not so perfunctory, for nine more items in the Geniza list stand out: wine, rose, apple, pear, virgin, woman, pretty face, musician, and the equivalent of jilwa' az, "tax collector". We shall leave this enigmatic item for last, after painting a picture around it, as it were, with the first eight. Kini. "What is life to a man without wine?" wonders Ben Sira, the literary sophisticate whose work in its Hebrew original the pioneer of Geniza studies, Solomon Schechter, was so elated to discover in the Cairene treasure trove. ${ }^{19}$ Readers of the Fatimid period would have appreciated the sentiment: "it is known," writes Paul Fenton, a modern researcher, "that drinking parties were a common feature of social life and the Genizah has even preserved some ancient drinking songs." People of different faiths mingled at drinking parties in the period, and there was music: a Muslim musician of thirteenthcentury Aden reported his three noble Jewish employers to the local qā $\bar{l} \bar{l}$ after an Eid alFitr celebration they hosted. The Israeli poet Dan Pagis published a number of the songs found in the Geniza. ${ }^{20}$ A wealthy Cairene Jewish home had a large central room, the

\footnotetext{
${ }^{18}$ Goitein, Vol. 4, pp. 174, 176, notes that white is the color most frequently mentioned in trousseaus (83 times); black, fifth (16 times). But the latter did not have the funereal associations of the West of the present day, and was considered "festive and dressy".

${ }^{19}$ Hoffman and Cole, p. 59. Schechter saw the discovery of the original Hebrew Ben Sira as vindication of his view that Second Temple Judaism was vital, lively, cultured, and human - not the legalistic, ritualistic monstrosity that biased Gentile Biblical scholars such as Wellhausen made it out to be.

${ }^{20}$ Paul B. Fenton, "Jewish-Muslim Relations in the Medieval Mediterranean Area," in Stefan C. Reif, ed., The Cambridge Genizah Collection: Their Contents and Significance, Cambridge: Cambridge University
} 
majlis, which could accommodate as many as four hundred guests: one entered through a hall called in Arabic by the Persian loan-word dahlīz (cf. Armenian dahlič). It might have marble walls, water flowing down a slab into a marble basin (called in Arabic, as in Armenian, by another Persian loan-word šädirwān), and a wind-tower for cooling like the Iranian $b \bar{a} d g \bar{i} r$. The majlis of the wealthy was illuminated at night hundreds of large and small candles, chandeliers, and oil lamps. Vart. A rose is a rose is a rose. We offer them as gifts, maybe grow them in gardens, and that's all: soap, after shave, and spray cans do the rest. But Cairenes used rose water in vast quantities - to rinse, freshen up, and cleanse a place of odors. The ubiquitous long-necked golābdān, rose-water dispenser, of repoussé silver one finds in modern India and Iran is a remote echo of those times. Geniza texts also mention such vessels as part of the basic furnishings of a good home. Our word list dutifully mentions bread and water: Cairenes had their drinking water from the Nile delivered by porters; and though homes had large storage jars and measuring cups for wheat, flour was ground at mills and the local baker's hot ovens were often employed for bread. Meat was a luxury item: fruits and vegetables were eaten in large quantities. Khach'ig has had a bite to eat, and they have begun drinking; Avraham offers him a sprinkle of rose water and some fruit. Danz, khnzor. Pears and apples are fruits of the north - locally, specialties of the Armenian plateau. The Armenian word for apple is an old one, Urartean, and the finest apples, proverbially, were those of Artamet near Van. Perhaps the Jewish owner of the word list wished to praise these in pleasant conversation.

Aghya akhshkin, kays, kusan. Ben Sira praises wine and warns that old men ought not to interrupt the music at a party with too much talk; and since slave girls and dancers figure as valuable property in Geniza lists, they perhaps formed part of the muchappreciated entertainment. The Jew and Armenian perhaps meet, then, in a wellappointed majlis at a drinking party where there are beautiful girls: Aghchign agheg e, kuys $e$ ? the two men wonder, perhaps wistfully. There are musicians, and singers. At this point, the party gets interesting - at least we have the word of the worried religious authorities. I have already mentioned consternation of the qadi in Aden- and the Muslim clergy of Egypt were regularly incensed by bibulous practices, which, one is pleased to report, they were quite unable to stop. As for the Jews, in the tractate 'Avoda zara ("Alien worship") of the Babylonian Talmud, 31b, the Rabbis warn that drinking parties lead to intermarriage. (And why do the ultra-Orthodox disapprove of sex? goes the modern joke. Answer: It leads to dancing!) Armenian divines through the ages have been no less severe in their condemnation of such entertainments. A sermon attributed to the fifth-century Catholicos Yovhannēs Mandakuni (more likely to be the work of another Catholicos John, Mayragomec'i, who lived three centuries later), "Concerning the lawless behavior of drunkards", warns sourly, "Bread ( $h a c$ ), water ( jur), and raiment requite the necessities of life; all the rest are a matter of desire, not of importance." Another sermon of the same author that has become the locus classicus for discussion of Armenian gusans, "Concerning the lawless theaters of the demonic", declares weakwilled women particularly susceptible to the lewd suggestions of drama: "For the custom itself is evil and so are those who encourage it: wine (gini), the minstrel (gusan), and Satan," where "women are cast into the role of prostitutes; and men, as rutting stallions

Press, 2002, p. 155; Dan Pagis, "Wine Songs preceding the Spanish period," Qoveș mehqarim (Dov Sadan Jubilee Volume), Jerusalem and Tel Aviv, 1977, pp. 245-255. 
mounting mares (jioc " matakaxazac )." There are also clowns or jesters at these performances: "For where jesters (katakk') and minstrels and lewd play (xat) and satire (catr) be; there the demons, too, join in the dance." These occasions involve wine, as one might expect: "For the theaters of the play are the encampments of the demons, as are all the immoral, minstrel-mad (gusanamol) wine-imbiber (ginarbuk' $n$ ), too." It is not just wine the demons give the performers: "And they pour more into the mouths of the lewd minstrels - many clownish jests and moronic speeches." Yovhannēs did not miss anything: he even has a reference to the pleasant fragrances employed at social gatherings, like the rose water of Cairo: "Woe to them who drink wine in order to become intoxicated, and who anoint themselves with sweet oils (anoyš iwłeawk)!"21 The kings of Armenia were fortunate in not having to take any account of such sermons:

$\mathrm{P}^{\prime}$ awstos Buzand reports that when Aršak II was imprisoned in the Sasanian Fortress of Oblivion, his faithful eunuch Drastamat urax arnēr zna gusanawk' "cheered him with minstrels"; and Pap died while nayēr ond pēs pēs ambox gusanac "n "he was gazing at a motley throng of minstrels". At least eight centuries later and hundreds of miles to the southwest, the poet Yovhannēs of T'lkuran still called himself a gusan. ${ }^{22}$ And the $12^{\text {th }}$ century law code Datastanagirk' of Mxit'ar Goš— closely contemporary to our fragment - is scandalized by such entertainments, which seem to be typical of the way of life of the privileged classes. "Some freemen and horsemen, when they arrive at villages which are situated in the region of a monastery, do not dismount at the village, but some with women (kanambk) and female servants (nažštawk) lodge at the monastery, and in this way trample on the canon of the fathers. With minstrels (gusanawk) and singing girls (varjakawk) they dine in the house of holiness and worship, which is horrible for Christians to hear, let alone see." 23

The invective against wine drinkers and minstrels refers also to satirical speech and to actors playing lewd roles as animals. The satire would have been both political and anti-clerical; and the actors would have required costumes and masks. One recalls that the English "satire" itself goes back to the lusty, ithyphallic Mischwesen, the half-men, halfbeasts who pursue youths and maidens across the surfaces of ancient Greek kraterswine-mixing bowls - and drinking cups. Might they provide a hint as to the meaning of the ninth and enigmatic term of our list, 'ștp'n mrt, i.e., some kind of man (mard, pronounced here /mart/)? Clackson reads the first word as estefan, and suggests, on the basis of the word it translates, Judaeo-Arabic jilwa 'az, that it is a deformation of ostikan, a high official (nowadays, just a cop). Let us return to the term Nowrūz, encountered above in the form Nairuz as the name of a Muslim Armenian who fought in Syria. The term is the familiar name of the Iranian New Year, a vernal festival commemorating Ahura Mazdā's creation of fire, which coursed through the other six sacred creations, animated them, and brought the new world into motion. The holiday became immensely

\footnotetext{
${ }^{21}$ Yovhannēs Mandakuni, Čark' (“Orations”), Venice: S. Lazzaro, 1860, pp. 130, 132, 134, 135, 136.

${ }^{22}$ J.R. Russell, Yovhannēs T'lkuranc 'i and the Mediaeval Armenian Lyric Tradition, University of Pennsylvania Armenian Texts and Studies 7, Atlanta, GA: Scholars Press, pp. 2-3.

${ }^{23}$ Robert W. Thomson, tr., The Lawcode [Datastanagirk'] of Mxit 'ar Goš, Dutch Studies in Armenian Language and Literature 6, Amsterdam: Rodopi, 2000, ch. 211, pp. 254-255. I have changed his translation slightly. For the text, see Xosrov T'orosyan, ed., Mxit'ar Goš, Datastanagirk', Erevan: Matenadaran, 1975, p. 121.
} 
popular in Egypt, with wine and beer consumed in public. Too much alcohol was as dangerous then as it is now: in Aleppo in the spring of 1022, 'Azīz al-Daula fell into a drunken slumber after a party and was assassinated by his two favorite ghulāms, one of whom happened to be an Armenian convert to Islam named Abū'l Najm Badr. ${ }^{24} \mathrm{~A}$ description of Nowrūz in Cairo in AD 975 mentions public performances of a carnivalesque character in which actors satirized, mocked, and punished officials, in an apparent overlay of customs associated with the Greco-Roman and succeeding Christian cultures of the Mediterranean. A twelfth-century source testifies that whores and transvestites carried musical instruments; and descriptions of Nowrūz in nineteenthcentury Egypt note that celebrants still wore costumes blasphemously parodying such otherwise dreaded officials as the tax man, the hangman, the flogger, and so on. ${ }^{25}$ Armenian Carnival or Mardi Gras - the feast of Barekendan — was also associated with such blasphemous and lewd plays of role-reversal. A chronicler of the era gives us a glimpse into contemporary celebrations of the holiday by Armenian traders, probably from the region of Lake Van, who seem to have been organized in a guild-brotherhood for, among other things, defensive purposes. "On the day of barekendan of the same year [i.e., in the 1120's], a caravan carrying salted fish [Arm., tarex] came to the city of Antioch from the East. The people belonging to this caravan had set themselves up in the marketplace and were drinking and making merry. When the townspeople heard the sounds of their dancing and singing, all the men of the city pounced upon them and beat them to a pulp, after which they began to throw them out of the city. Now the men of this caravan were eighty in number and they had truncheons and were resolute in purpose. So when their guild-leader [manktawagn noc 'a] cried out to them, in their drunken condition they fell upon the townspeople, pursuing them from the Gate of Sewodn [Arm., "Blackfoot"] to the Church of Saint Peter, they put all the townspeople to flight and broke the skulls and bones of many. Finally, the Antiochenes swore by the cross and the Gospels that they would never bother them again. So, after peace was reestablished, the caravan returned to its place of origin." 26

Minas of Tokat, an Armenian clergyman of L'vov (Austro-Hungarian Lemberg, Ukrainian L'viv, Polish Lwów, home to all those peoples, Jews, Kipchaks, and a great many Armenians at one time) in the Eastern European region of Galicia, wrote on Friday, 5 February 1563, a semi-satirical ode, Govut 'iwn i veray herisayi, in praise of the rich festival porridge called herisa or keshkek by Armenians. It includes this quatrain: "Shrovetide is near,/ The hour of joy has come,/ The Abetat 'ot rite is near,/ And

\footnotetext{
${ }^{24}$ Dadoyan, p. 110.

${ }^{25}$ Boaz Shoshan, Popular culture in medieval Cairo, Cambridge: Cambridge University Press, 1993, pp. 42, 43, 50, 59. For the non-Muslims of Fatimid Cairo (and, indeed, of many other Muslim climes at many other times, too), who were required as dhimmis to pay the additional, punitive jizya tax, the internal revenue service of the day inspired even greater dread than it does among Americans in mid-April nowadays.

${ }^{26}$ Armenia and the Crusades, 10th to 12th centuries: the Chronicle of Matthew of Edessa, translated and edited by Ara Edmond Dosturian (Lanham 1993), pp. 148-149. Armenian text: Matt'eos Urihayec'i, Žamanakagrut 'iwn ["Chronicle"], ed. M. Melik'-Adamean and N. Tēr-Mik'aelean, Vałaršapat, 1898 , p. 226. I am indebted for this reference to my former student and present colleague Dr. Rachel Goshgarian, from her excellent work on the Armenian fraternal orders of the Erznka/Erzincan area.
} 
Mort 'êt 'ot 'ovn! is said" (lines 37-40). Abełat'ot, which means "leaving the monastic rule", is a Shrovetide parade, a blasphemous parody of the monastic perambulation of a church. The Shrovetide shout Mort 'êt' ot 'ovn! which I understand as "Skin the stammerer!" has most likely to do with the mock-flaying of the aycemard, or "goatman"- a man or boy dressed in a goat costume. The custom, which still existed among Armenians of $19^{\text {th }}$-century Tiflis, was described by observers, and there is even a drawing of the aycemard, a man with a staff in a goat mask - both goat and goat-herd - that is, a "goat-herd man" ${ }^{27}$ This creature, part man and part animal, is a remote echo of the satyr; and as for the act of flaying, one recalls that young men of the Equestrian order killed and flayed an actual goat on Roman Lupercalia. They then ran through the streets, smeared with blood, striking women with strips of goat hide to make them fertile. The februa, or switches, used in Lupercalian rites have indeed given the month of February, when all this went on, its very name. Now let us return to the drinking party and the young girls and minstrels in the Cairo majlis. Might it be the carnivalesque Nowrūz, with a gusan in lupercalian costume representing some mutually feared and despised official to be harmlessly mocked? If so, might then our enigmatic phrase be read as *atstpan mart, that is, acpan mard, "goat-herd man", with the mysterious first word a rendering of the attested form in Middle Armenian, and the phrase entire a medieval equivalent of the aycamard, "goat-man", of the Shrovetide revels of Tiflis in more recent times? ${ }^{28}$ The obvious problem and objection to this suggestion is that this term does not directly translate "tax collector" and my suggestion is that the latter was being satirized; so the word list here employs a very particular paraphrase. Another possible reading, closer to a direct translation of jilwa 'az, might be advanced: *atat 'pan, "keeper of order", as a compound with the common Arabic loan variously spelled adat', adèt ' in Middle Armenian. One's reconstruction of the social scene might have to part with its satyr; but I mean to revive him one last time.

Wine is poured, fruit is eaten, a minstrel sings. Then one realizes that one has only been gazing at a sheet of paper. Our revels now are ended, Prospero declared as the cloud-capped towers melted away. Federico Fellini once made a film based upon the Satyricon of Petronius, a book brimming with realia (and satyrs!) that takes us through the feasts, drinking parties, music, entertainments, and debauchery of Imperial Rome, about as long before the celebration in medieval Cairo I have attempted to reconstruct as we now stand after it. At the end of the film the speech of one of the two protopicaresque young heroes stops in mid-sentence, and his face becomes a fragment of a ruined ancient fresco in the sun; beyond it, the indifferent and eternal blue of the Mediterranean. From this literal fragment of an Egyptian Jew's book I have sought, with some imaginative audacity for which I crave your indulgence, to shore up my ruins, and your own.

The Fatimid Cairenes, as I have said, were at an equal temporal remove from both Rome and ourselves. But this equivalence of chronology is deceptive. Much of their

\footnotetext{
${ }^{27}$ J.R. Russell, “The Praise of Porridge," Le Muséon 116.1-2, 2003, pp. 137-179 (AIS, pp. 1217-1260): the aycemard, "goat-man" of the Barekendan revels, is illustrated in pl. 1, p. 171/1259, from V. Bdoyan, Hay žotovrdakan xater (“Armenian folk games"), vol. 1, Erevan, 1963, p. 147 pl. 11.

${ }^{28}$ Mijin hayereni bararan, vol. I, p. 21 s.v. acpan.
} 
world endured, little changed; and we have only recently been severed from it, root and branch. The drinkers of Tiflis in the mid $-18^{\text {th }}$ century could still hear the living voice of a great Armenian gusan, the polyglot bard Sayat' Nova, who wrote Tatar in the Armenian script of Maštoc'; and Armenian, in the intricately curvilinear Georgian mkhedruli. His world, with its cosmopolitan conviviality, its wine and wit, its roses and delicate maidens, its absorption in music and love, its gatherings in the majlis, is not too far from that of eleventh-century Cairo. But the master minstrel, cited in the second epigraph to this paper, was wrong when he sang that without him wine parties would not lack for the sound of stringed instruments. The culture that Indian and Ethiopian, Arab, Armenian, and Jew had shared soon followed his departure from the earth. In the $11^{\text {th }}$ century, Christian and Muslim Armenians wrote mystical songs, fought, traded, wove rugs, cut stone, and cast bronze in Syria, where the easternmost waves of the Mediterranean end their long journey from the Pillars of Hercules and break below the forested spurs and foggy chasms of Musa Dagh. That life ended, in 1915, when the embattled Armenian villagers of the mountain withstood the onslaught of the world's first genocidal state. Though many of them survived, still by the end of the Great War, most of Armenia was gone. In the first epigraph, the French wife of the leader of the fedayis, the Armenian fighters on the mountain of Moses, exclaims, No European can learn your language. The isolation of Armenian the language has become the metaphor of Armenia the nation itself, an island of civilization nearly alone in a darkening and raging ocean. There were no more phrase books through which a Jew and a Christian in a Muslim capital might enjoy together a Persian new year's drinking party spiced by the theatrical relics of Roman debauchery. For The Forty Days of Musa Dagh are the work of Franz Werfel, a Jew from Austria. He imagined in the fateful year 1933 the plaintive words of Juliette Bagratian; the Nazis burned his book, and within a decade most of the Jews of Europe, too, had been murdered. There are fewer than a hundred Jews alive in Egypt today: the Ibn Ezra synagogue has become itself a geniza, a storehouse inhabited by ghosts.

Ašxarz me panjara ē, sang Sayat' Nova. "The world is but a window," into the beyond. Tałerumēn pezaril im, "And I am tired of its panes." (The pun, pane/pain, on window frame and hurt works here as well in English as in Armenian.) Ereka lav èr vunc" vor aysōr;//Vałerumēn pezaril im: "Yesterday was better than today;/ And I am tired of the morrow." The majlis of the western world I inhabit seems too often a study in loneliness together: isolated faces around cheerless tables, each face fixed upon the balefully glowing screen of a laptop. Conversation itself is fragmented into the one-sided stridor of voices on cell phones. The salt, as Christ warned us, has lost its savor. But there are still places on the ruined and dying planet a delicate instrument is tuned, there is free and articulate conversation, a beautiful face may still be seen, a song is sung, and somebody pours a friend a glass of wine. Where I live, in Cambridge, Massachusetts, a singer named Peter from southern Russia plays his guitar on warm nights in front of the $\mathrm{Au}$ Bon Pain café on Harvard Square. During the winter he plays at an Armenian restaurant. When I told him I had written a paper to read in Erevan, he said, Don't forget to mention Okudzhava! This was something of a joke, since whenever he sees me sitting at the café or walking past on Massachusetts Avenue, Petya plays my favorite, Okudzhava's song Ваше благородие, госпожа удача ("Your ladyship, Madame Fortune") from the good old Soviet movie Белое солнце пустыни, "The White Sun of 
the Desert". But in fact I already had done so, in the draft, and here it will stay. If the old bards are gone, there are others, still, to make our celebrations human amidst the hideous inversion of life of a nightmare age: Bob Dylan, Vladimir Vysotsky. And Bulat Okudzhava. His poetic voice emerged from the Russian, Armenian, Georgian, and Jewish cultures of Moscow and Tiflis, of a vast and undivided country we once knew, a sorrowful and joyful country, but one we loved. In his song he pleads with his own hero in art to carry on: Моцарт на старенькой скрипке играет,/ Моцарт играет и скрипка поет./ Моцарт отечества не выбирает,/ Только играет всю жизнь напролет./ Ах, ничего, что всегда, как известно,/ Наша судьба то гульба, то пальба-/ Не обращайте вниманья, маестро,/ Не убирайте ладони со лба. "Mozart plays an antique violin:/ Mozart plays, and the violin sings./ Mozart chooses no fatherland for himself,/ Just plays his whole life away./ Oh, it doesn't matter that, as we know,/ Our fate is ever thunder and a howl./ Pay them no attention, master!/ Don't take your palm from your brow." 


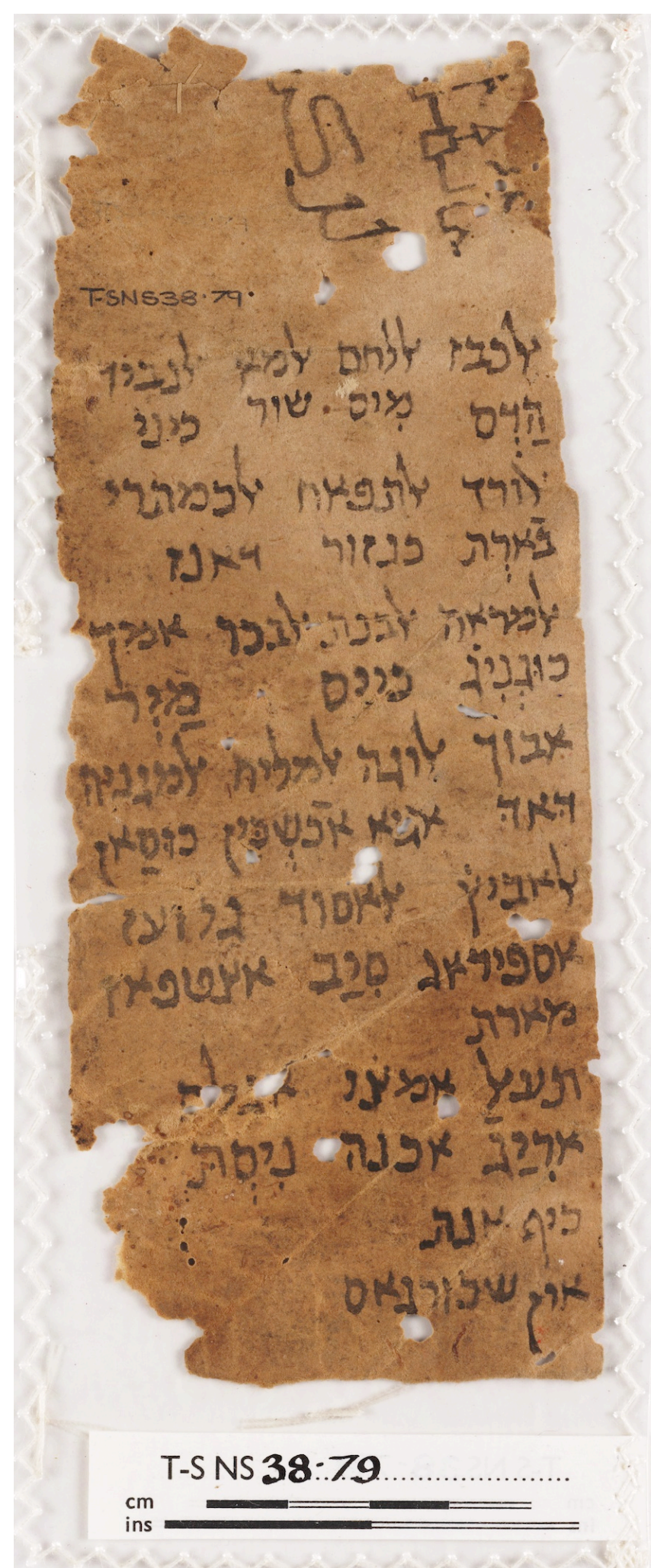

The Cairo Geniza Judaeo-Arabic and Armenian word list, T-S NS 38.79 (T-S NS 176.2). 